\title{
Antibody-Drug Conjugate DFRF4539A
}

National Cancer Institute

\section{Source}

National Cancer Institute. Antibody-Drug Conjugate DFRF4539A. NCI Thesaurus. Code C106256.

An antibody-drug conjug ate (ADC) composed of a monoclonal antibody directed against a specific myeloma antigen and conjug ated to monomethyl auristatin E (MMAE), an auristatin derivative and a potent microtubule inhibitor, with potential antineoplastic activity. Upon administration, the monoclonal antibody moiety of DFRF4539A selectively binds to a specific protein expressed on the surface of myeloma cells. Upon internalization and proteolytic cleavage, MMAE binds to tubulin and inhibits its polymerization, which results in G2/M phase arrest and tumor cell apoptosis. 